\section{Canadian Journal of Forest Research}

\section{Journal canadien de recherche forestière}

Volume $18 \quad$ numéro $7 \quad$ juillet 1988
B. M. Cregg, P. M. Dougherty, and T. C. Hennessey

K. L. O'Hara

C. L. Tuttle, D. B. South, M. S. Golden, and R. S. Meldahl

M. T. Dumas

George H. La Roi, Wayne L Strong, and Donald J. Pluth

E. O. Robertson and L. A. Jozsa

David G. Brand and Steen Magnussen

Louis A. Ballard and James N. Long

P. Chakravarty and L. Chatarpaul

J. Gagnon, C. G. Langlois, and J. A. Fortin

F. Courchesne et W. H. Hendershot

M. Rafique Uddin, Martin M. Meyer, Jr., and J. J. Jokela

Everett M. Hansen and Donald J. Goheen

Lindsey E. Rustad and Christopher S. Cronan

R. C. Yang, E. I. C. Wang, and M. M. Micko

W. J. Bloomberg and H. Brix

Hank A. Margolis, Jacques Bégin, Richard Beeson, and Pierre Bellefleur
ARTICLES

827-832 Basal-area projection equations for thinned natural even-aged forest stands

833-850 A dynamic simulation of loblolly pine (Pinus taeda L.) seedling establishment based upon carbon and water balances

851-858 Growth and wood quality of young loblolly pine trees in relation to stand density and climatic factors

859-866 Stand structure and growing space efficiency following thinning in an even-aged Douglas-fir stand

867-871 Initial Pinus taeda seedling height relationships with early survival and growth

872-874 Biological species of Armillaria in the mixedwood forest of northern Ontario

875-887 Understory plant community classifications as predictors of forest site quality for lodgepole pine and white spruce in west-central Alberta

888-900 Climatic reconstruction from tree rings at Banff

901-910 Asymmetric, two-sided competition in even-aged monocultures of red pine

911-916 Influence of stand density on log quality of lodgepole pine

917-921 The effects of Velpar L (hexazinone) on seedling growth and ectomycorrhizal symbiosis of Pinus resinosa

922-929 Growth and ectomycorrhiza formation of containerized black spruce seedlings as affected by nitrogen fertilization, inoculum type, and symbiont

930-936 Cycle annuel des éléments nutritifs dans un bassinversant forestier : contribution de la litière fraîche

937-941 Plantlet production from anthers of Eastern cottonwood (Populus deltoides)

942-946 Rate of increase of black-stain root disease in Douglasfir plantations in Oregon and Washington

947-953 Element loss and retention during litter decay in a red spruce stand in Maine

NOTES

954-956 Effects of fertilization on wood density and tracheid length of 70 -year-old lodgepole pine in west-central Alberta

957-961 Effect of root injury and auxin treatments on adventitious root development in second-growth Douglas-fir

962-964 The influence of metal halide and high-pressure sodium lamps during photoperiod extension on the allocation of carbon between lignin and cellulose in black spruce seedlings 
Canadian Journal of Forest Research

$\begin{array}{lll}\text { Volume } 18 & \text { Number } 8 & \text { August } 1988\end{array}$

\section{Journal canadien de recherche forestière}

Volume 18 numéro 8 août 1988

\section{REVIEW/SYNTHĖSE}

Peter J. Parks and Ralph J. Alig

965-973

\section{ARTICLES}

Michael J. Peterson, Jack. R. Sutherland, and S. E. Tuller

Peter A. Cardellichio and Clark S. Binkley

R. C. Beeson, Jr., and W. M. Proebsting

D. M. Rizzo and T. C. Harrington

Greg S. Biging

D. G. Leckie, P. M. Teillet, G. Fedosejevs, and D. P. Ostaff

P. M. Catling and K. W. Spicer

Risto Sievänen, Thomas E. Burk, and Alan R. Ek

J. K. Meil and J. C. Nautiyal

D. M. Van Ryn, J. P. Lassoie, and J. S. Jacobson

E. M. Hansen and P. B. Hamm

Robert E. Farmer, Jr., Karen Garlick, and Steven R. Watson

Laura E. Conkey

R. Ceulemans, I. Impens, and V. Steenackers

R. E. Farmer, Jr., W. M. Cheliak, D. J. Perry, P. Knowles, J. Barrett, and J. A. Pitel

Ole T. Helgerson, Kermit Cromack, Susan Stafford, Richard E. Miller, and Rod Slagle

Claire G. Williams

Craig Wallace Hedman and Dan Binkley

Paul C. Van Deusen

974-980

981-985

986-990

$1036-1048$

NOTES
1002-1007 Estimating the accuracy of volume equations using taper equations of stem profile

1008-1016 Reflectance characteristics of cumulative defoliation of balsam fir

1017-1026 The separation of Betula populifolia and Betula pendula and their status in Ontario

1027-1035 Construction of a stand growth model utilizing photosynthesis and respiration relationships in individual trees

An intraregional economic analysis of production structure and factor demand in major Canadian softwood lumber producing regions

1049-1052 Effects of acid mist on in vivo pollen tube growth in red maple

1053-1058 Canker diseases of Douglas-fir seedlings in Oregon and Washington bareroot nurseries

1059-1062 Heritability and $C$ effects in a 3-year-old balsam poplar clonal test

1063-1068 Decline in old-growth red spruce in western Maine: an analysis of wood density and climate

1069-1077 Genetic variation in aspects of leaf growth of Populus clones, using the leaf plastochron index

1078-1081 Isozyme variation in balsam poplar along a latitudinal transect in northwestern Ontario

1082-1085 Equations for estimating aboveground components of young Douglas-fir and red alder in a coastal Oregon plantation

1085-1089 Accelerated short-term genetic testing for loblolly pine families

1090-1093 Canopy profiles of some Piedmont hardwood forests

1093-1096 Simultaneous estimation with a squared error loss function 